Г. В. Давыдова

Байкальский государственный университет, г. Иркутск, Российская Федерация

О. С. Козлова

Байкальский государственный университет, г. Иркутск, Российкая Федерация

\title{
ВЛИЯНИЕ ЖИЗНЕННОГО ЦИКЛА НЕФТЕДОБЫВАЮЩЕЙ ОТРАСЛИ НА СТРАТЕГИЧЕСКИЕ АЛЬТЕРНАТИВЫ ЕЕ РАЗВИТИЯ
}

\begin{abstract}
АНнОтАЦИЯ. В статье представлены теоретические исследования по необходимости учета этапов жизненного цикла отрасли при формировании стратегии ее развития. $\mathrm{C}$ этой целью разработан методологический подход к формированию фаз жизненного цикла ресурсных отраслей, к которым относится и нефтедобыча. Выявлены причины циклического развития отрасли на каждом этапе жизненного цикла, сформированы направления возможного увеличения длительности каждого этапа. В качестве математического инструментария обоснования выделения этапов реализации стратегии роста добычи нефти предлагается использовать логистические кривые, с помощью которых можно рассчитать определенный прогнозный уровень (предел насыщения) в сложившихся технико-экономических условиях. Для его преодоления необходим «качественный скачок» в точке «перегиба» (замедление темпов), что приводит к переходу отрасли на новый уровень развития (альтернативная стратегия).
\end{abstract}

кЛЮЧЕВЫЕ СЛОВА. Жизненный цикл; фазы жизненного цикла; нефтедобывающая отрасль; стратегия развития.

ИНФОРМАЦИЯ О СТАТЬЕ. Дата поступления 22 июля 2016 г.; дата принятия к печати 23 августа 2016 г.; дата онлайн-размещения 30 сентября 2016 г.

G. V. Davydova

Baikal State University,

Irkutsk, Russian Federation

O. S. Kozlova

Baikal State University,

Irkutsk, Russian Federation

\section{IMPACT OF LIFE CYCLE OF OIL-PRODUCING INDUSTRY ON STRATEGIC ALTERNATIVES OF ITS DEVELOPMENT}

\begin{abstract}
The article presents theoretical research on necessity of considering stages of the industry life cycle in developing the strategy of its development. With this object in mind, a methodological approach is worked out for developing the life cycle phases of resource industries which include oil production. The article identifies the causes of cyclical development of the industry at every stage of the life cycle, shapes directions of possible increase in the duration of each stage. As a mathematical tool for substantiating the identification of the stages of implementing the strategy of oil production growth, it offers to use logistic curves that enable to calculate a certain forecast level (saturation limit) in the current techno-economic environment. Overcoming it requires a «qualitative leap» at the point of the «bend-over» (slackening the rate) which results in transition of the industry to a new development level (alternative strategy).

KEYWORDS. Life cycle; life cycle phases; oil production industry; development strategy. ARTICLE INFO. Received July 22, 2016; accepted August 23, 2016; available online September $30,2016$.
\end{abstract}

(ㄷ) Г. В.Давыљова, О.С. Козлова, 2016

\section{Baikal Research Journal}


Многолетний опыт разработки и практического использования стратегий развития страны, регионов, отраслей и предприятий показал, что в среднем точность их реализации колеблется от 50 до 80 \%. Следовательно, необходимо продолжать теоретические исследования по повышению точности формирования стратегий развития отраслей. На наш взгляд, одним из направлений повышения точности формирования стратегий развития отраслей страны может являться учет этапов жизненного цикла отрасли, на котором она находится на момент разработки стратегии, поэтому мы считаем методологически необходимым остановиться на рассмотрении закономерностей развития отрасли. Следует отметить, что «существует ограниченное количество общих теорий отраслевого развития, что объясняется широким разнообразием в сочетании ключевых факторов производства, определяющих динамику развития той или иной отрасли, и не позволяет оценивать результаты этого развития по унифицированной методологии» [1].

В соответствии с концепцией жизненного цикла отрасль в ходе своего развития проходит четыре этапа: выход на рынок, рост, зрелость и спад [2]. Эти этапы определяются моментами изменения темпов роста отраслевого объема продаж.

M. Портер характеризует каждую стадию жизненного цикла отрасли с точки зрения развития конкуренции. На каждой стадии он присваивает отрасли определенные характеристики, такие как число и размер фирм, уровень технологической и стратегической неопределенности, экономические показатели, барьеры входа, выхода, мобильности, а также свойственные отрасли характеристики конкурентов и интенсивность конкуренции.

Концепция жизненного цикла отрасли подвергалась критике по следующим позициям:

1. Продолжительность стадий жизненного цикла в отраслях различна для каждой отрасли, и часто не ясно, на какой из стадий находится отрасль. Этот недостаток снижает полезность концепции жизненного цикла в качестве инструмента планирования.

2. Рост отрасли не всегда следует S-образной модели.

3. Компании в состоянии влиять на характер кривой роста с помощью освоения новой продукции и репозиционирования, а также преодолевать его различными способами.

4. Характер конкуренции, присущий каждой стадии жизненного цикла, различен в разных отраслях.

M. Портер отмечает, что, несмотря на обоснованную критику, концепция жизненного цикла может быть применена для исследования эволюционных процессов, в результате которых происходят изменения в отраслях. «Процессы эволюции двигают отрасль в направлении ее потенциальной структуры, которую нельзя знать заранее, поскольку ее формирование продолжается до тех пор, пока эволюционирует отрасль. Тем не менее, базовая технология, характеристики продукта, природа существующих и потенциальных покупателей определяют ряд вероятных вариантов структуры отрасли, к которым она может прийти в зависимости от направлений и результатов, осуществляемых в ней исследований и разработок инноваций в сфере маркетинга и т. п.» [2, с. 213].

Таким образом, М Портер считал, что концепция жизненного цикла помогает понять эволюционные изменения, протекающие в отрасли, однако одной ее для объяснения всех изменений недостаточно. Стадии жизненного цикла определяют темп роста отрасли. Однако ситуация в отрасли меняется не только в связи с переходом на новую стадию цикла, но и под влиянием движущих сил. М. Портер отмечает, что «огромную роль в эволюции играют инновации, технологические достижения, индивидуальные особенности (и ресурсы) конкретных фирм как уже

\section{Baikal Research Journal}

электронный научный журнал Байкальского государственного университета 
действующих в отрасли, так и собирающихся в нее войти. По этой причине отрасль может иметь различную судьбу, эволюционировать разными путями и с различной скоростью, а достоверное прогнозирование ее эволюции является сложной задачей» [2, с. 214].

Сегодня большинство исследователей связывают долгосрочный переход к устойчивой экономической модели, прежде всего с использованием инноваций. Эволюционная теория в целом и теория устойчивости развития экономических систем приводят к выводу о том, что решающим фактором развития отрасли являются инновации. При этом необходимо учитывать, что инновационное развитие на уровне отрасли имеет специфические особенности по сравнению с инновационным развитием национальной экономики.

Фаза жизненного цикла характеризует базовые условия функционирования отрасли, темпы роста производственной деятельности, характер спроса на отраслевой продукт, уровень инвестиций. Указанные параметры определяют состояние и ключевые характеристики отраслевого рынка. Так, в фазе рождения (выход на рынок), когда происходит становление отрасли, отраслевой рынок не монополизирован, его структура подвижна и зависит от скорости формирования спроса на отраслевой продукт. На фазе роста происходит постепенное укрупнение предприятий, действующих в отрасли, рынок приобретает монопольные черты, агрессивная конкурентная политика вытесняет более слабых производителей с рынка. На фазе зрелости отрасль характеризуется устойчивым состоянием сложившейся на фазе роста структуры отраслевого рынка, когда появление новых производителей связано с необходимостью оживления развития отрасли, диверсификацией деятельности, освоением новых географических регионов. На фазе спада крупные производители уводят активы в более прибыльные сферы применения [3; 4].

Все факторы развития отрасли можно разбить на традиционные и инновационные. К традиционным факторам исследователи относят выгодное географическое положение, обеспеченность большими запасами ресурсов, относительно низкие цены на основные факторы производства, а к «новым» факторам - внедрение инноваций, развитие образования, применение информационных технологий и др. Отмечается, что в настоящее время традиционные факторы утрачивают свое значение. Степень значимости традиционных факторов для ресурсных отраслей имеет свою специфику, отличающую их от других отраслей экономики. Ресурсные отрасли привязаны к местам размещения ресурсов, и в силу этого не могут оказывать влияние на традиционные факторы, что делает их значимость очень высокой, вне зависимости от фазы жизненного цикла отрасли [5].

Нефтедобывающая отрасль относится к ресурсным отраслям. Применительно к ней значимость традиционных факторов объясняется следующими обязательствами. На нефтедобыче специализируются регионы, где разведаны запасы нефти. Выгодность географического положения в данном случае будет проявляться не только в наличии месторождений и их запасов, но и в удаленности рынков сбыта и центров потребления нефтепродукции, существовании относительно дешевых способов ее доставки потребителям, а также в климатических условиях и уровне их благоприятствования для осуществления добычи.

Часть традиционных факторов формируется на микроуровне. Производственный потенциал, придающий группе предприятий отраслевые признаки, и финансовые ресурсы предприятий - традиционные факторы отраслевого характера, но формируются они и находятся в сфере влияния предприятий. Поскольку инновации зарождаются на уровне отраслевых фирм, а задача разработки механизма их распространения должна решаться на отраслевом уровне, то инновационные факторы развития создаются отраслью и находятся в сфере ее влияния. Инновационные

\section{Baikal Research Journal}

электронный научный журнал Байкальского государственного университета 
факторы, связанные с инновационной деятельностью предприятий, формируются и управляются ими.

В настоящее время основополагающими факторами, которые способствуют ее переводу на качественно новый тип развития, позволяющий приобретать важные свойства, являются конкурентоспособность и стабильность. Конкурентоспособная отрасль в большей степени подвержена положительной экономической динамике, находится в более выгодных условиях в отношении инновационного развития, чем ее оппоненты по конкурентной борьбе. При этом конкурентоспособность не только стимулирует инновационное развитие, но и является производным результатом инновационных усилий. Другими словами, инновационность и конкурентоспособность оказывают взаимоусиливающее влияние, и это получило название «петли взаимного усилия» [6].

К. В. Садченко указывает, что жизненный цикл не исчезает, не завершается в «никуда», а лишь переходит из одной фазы к другой, а эволюционизирующие структуры перераспределяются из одного состояния в другое, от одной формы к другой. «Завершение есть начало нового процесса. Такова природа окружающего мира нелинейных процессов» [7]. Следовательно, концепция жизненного цикла отражает циклическую закономерность развития и убывающей эффективности совершенствования экономических систем. Предлагаемые разными авторами модели жизненного цикла экономических систем имеют некоторые общие черты: возраст, объем, темп роста системы на разных стадиях развития. Многочисленные концепции жизненного цикла подтверждают его нелинейность, причем каждый этап (выход на рынок, рост, зрелость, спад) является следствием предыдущего и эту закономерность невозможно нарушить. Однако модель жизненного цикла предполагает возможность разветвления на альтернативные траектории развития. Таким образом, важной задачей исследования жизненного цикла любой системы становится выявление точек разветвления и выбор наилучшей из всех возможных альтернатив развития.

В разных странах одни и те же отрасли могут находиться на разных стадиях жизненного цикла, эти различия определяются состоянием и динамикой рынка. Жизненный цикл отрасли может меняться под воздействием спроса, развития конкуренции, появления и распространения новых знаний (новые технологии производства, новые товары-заменители, новые потребности), изменения отраслевого окружения.

Нефтедобывающая отрасль является одной из отраслей специализации Российской Федерации. Состояние запасов, уровень добычи и переработки нефти, характер производимой продукции будут различны в разные периоды функционирования отрасли. Это позволяет выдвинуть гипотезу, согласно которой функционирование нефтедобывающей отрасли укладывается в рамках концепции жизненного цикла.

Для выделения фаз жизненного цикла нефтедобывающей отрасли Российской Федерации проанализированы данные, отражающие динамику развития отрасли с 1930 по 2015 гг. Следует отметить, что добыча нефти в мире и стране началась значительно раньше. Первая нефтяная скважина в мире была пробурена на Биби-Айбатском месторождении вблизи Баку в 1846 г., более чем на десятилетие раньше, чем появилась первая скважина в США (Пенсильвания, 1859 г.) [8]. Промышленное освоение нефти в России относится, на наш взгляд, к 30 -м гг. ХХ столетия. К примеру, с 1892 по 1917 гг. Россия занимала первое место в мире по добыче нефти. Объем ее добычи в 1917 г. составил 10,84 млн т. Таков был спрос.

Фаза выхода на рынок продолжалась с 1930 по 1960 г. (рис. 1). Главной функцией отрасли в этот период являлось удовлетворение спроса на данный ресурс. Так, с 1930 по 1960 г. добыча нефти возросла в восемь раз. Максимальная добыча (147,9 млн т)

\section{Baikal Research Journal}


наблюдалась в 1960 г. Среднегодовая добыча в целом за этот период составила 44,6 млн т, среднегодовой прирост нефтедобычи - 7,3 млн т (около 8 \% в год).

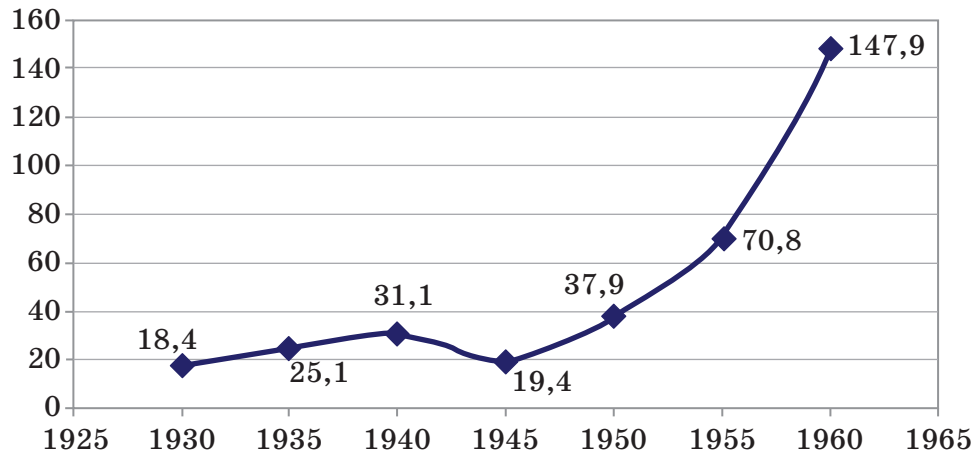

Рис. 1. Динамика нефтедобычи в Российской Федерации в 1930-1960 гг., млн т (Источник: URL : Istmat.Info promyshlennost_sssr_1957.pdf)

Несмотря на то, что производственная база была слабая, шло постепенное совершенствование технологий и методов добычи. Социальная инфраструктура эксплуатируемых месторождений тоже была слабой, хотя и способствовала закреплению людей на пионерных территориях. Основная особенность зарождающейся отрасли - отсутствие производственной и социальной инфраструктуры в районах пионерного освоения.

Весь период первой фазы жизненного цикла характеризуется поступательным ростом добычи нефти за исключением периода Великой Отечественной войны. Война 1941-1945 гг. нанесла существенный ущерб районам Северного Кавказа, что повлияло и на снижение объемов добычи нефти зарождающейся отрасли. В послевоенное время, восстанавливая нефтедобывающие комплексы Грозного и Майкопа, параллельно вводились в разработку месторождения Волго-Уральской нефтяной платформы. В 1960 г. она уже давала около 71 \% нефти. В 1950 г. добыли 37,9 млн т, а в 1960 г. - почти в четыре раза больше $(147,9$ млн т).

Указанные параметры отрасли, характеризовавшие ее в 1930-1960 гг., позволяют сделать вывод о том, что отрасль находилась на стадии рождения (выход на рынок). Вторая фаза (фаза роста) продолжалась с 1961 по 1990 г. В течение этой фазы сформировалась, а затем модернизировалась структура органов управления отраслью (рис. 2).

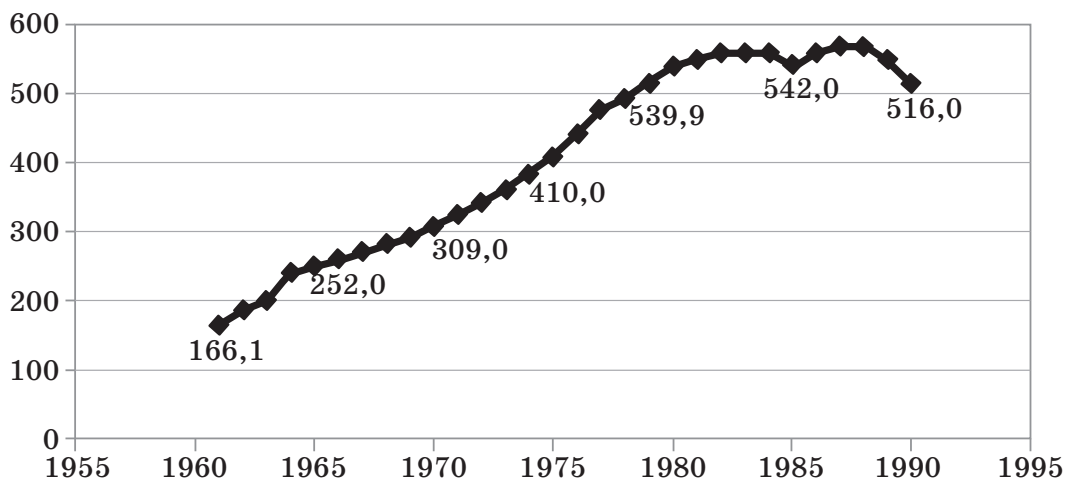

Рис. 2. Диналика добычи нефти в 1961-1990 г2., млн т (Источник: URL: http://www/gks.ru)

\section{Baikal Research Journal}


Объемы добычи нефти на фазе роста несопоставимы с показателями фазы рождения отрасли. В целом за 1961-1990 гг. среднегодовой объем добычи составил 409,8 млн т, а средний ежегодный прирост добычи - 12,8 млн т, или 4,2 \% в год.

Характерной особенностью фазы роста стало не только формирование вертикали управления отраслью, но и развитие внутриотраслевой кооперации и специализации. В 1960-1990 гг. нефтедобыча развивалась быстрыми темпами. Стремительно росло ее потребление и значительно расширялось производство по ее переработке. В середине 60 -х гг. XX в. были открыты гигантские месторождения Западной Сибири, разведали также новые месторождения в Прикаспии, на Северном Кавказе и Европейском Севере. Пик нефтедобычи в России пришелся на 1987-1988 гг., а затем она начала сокращаться, что было связано с общим упадком экономики. На этом этапе радикальных изменений в области добычи и транспортировки нефти, как и в предыдущие периоды, не происходило.

Период роста отрасли - это период триумфального развития нефтедобычи за счет освоения Западно-Сибирской провинции, благодаря которой нефтегазовый комплекс при практически не изменившейся структуре капитальных вложений развивался невиданными темпами. Главтюменьнефтегаз, дававший в 1965 г. порядка 0,9 млн т, нарастил добычу нефти к концу 1985 г. до 352,7 млн т, что составило $65 \%$ от всей добытой нефти. Нефтяная промышленность заняла лидирующие позиции в мировой добыче. Появились большие возможности для наращивания экспорта нефти и зарабатывания нефтедолларов. Этот же период называют периодом «посадки» на «нефтяную иглу» [9].

На фазе роста происходило совершенствование технологической базы производства, так как ее характеризовали следующие показатели:

- среднегодовая добыча нефти выросла с 44,6 млн т на фазе рождения до 409,8 млн т на фазе роста, т. е. в 9 раз;

- была создана материально-техническая база добычи, внутриотраслевая и межотраслевая интеграция, а организация управления отраслью приобрела жесткую вертикальную структуру;

- изменилась структура потребления нефти, т.е. большая часть ее направлялась на экспорт с целью «затыкания» черных дыр в отечественной экономике (в основном, на импорт продовольствия и закупку товаров народного потребления), но не на повышение технологического уровня отрасли;

- наивысшие показатели производительности труда в отрасли (отношение объема добычи к численности работающих в отрасли).

Третья фаза (фаза зрелости) началась в 1991 г. Она совпала по времени с периодом экономических реформ в России, которые привели к разрушению хозяйственной системы отрасли. В нефтедобывающей отрасли России наступил период затяжного кризиса, который удалось преодолеть только в 1998 г. Нефтедобывающая отрасль оказалась в глубокой депрессии. Если в 1990 г. объем добычи нефти составил 516 млн т, то в 1999 г. - 305 млн т, или $59 \%$ к 1990 г.

В 90-е гг. XX столетия в российском нефтяном секторе произошли существенные изменения в структуре управления. Единый производственный комплекс был расформирован, а на его базе создали вертикально-интегрированные компании (ВИНК). Основная часть ВИНК перешла в частную собственность. Процесс формирования собственно ВИНК начался в 1992 г. и получил новый импульс в 19941995 гг. Он прошел через этап приватизации и этап передела собственности (сначала с использованием процедур банкротства и вывода активов, впоследствии через более цивилизованные механизмы слияний и поглощений). История функционирования ВИНК и их модернизация насчитывает около 10 лет.

\section{Baikal Research Journal}

электронный научный журнал Байкальского государственного университета 
Увеличение объемов добычи нефти и расширение инвестиционных возможностей в начале 2000-х гг. повлияло на объемы экспорта нефти. Если в 2000-2004 гг. прирост добычи нефти составил 6-10 \% в год, то в 2005-2007 гг. - $2 \%$, однако в 2008 г. впервые за последние годы наблюдалось снижение объема добычи (экономический кризис в стране). За период с 2009 по 2015 г. среднегодовой прирост добычи составил $1 \%$. Позитивное влияние на динамику нефтедобычи оказали ввод в эксплуатацию нескольких крупных месторождений на севере Европейской части страны и в Восточной Сибири.

Более половины российской нефтедобычи сосредоточены в районах Урала и Западной Сибири. Большинство месторождений этих регионов отличаются высокой степенью выработки и потому, сохраняя его в качестве основной базы нефтедобычи, необходимо активнее развивать и альтернативные регионы добычи. Значительная часть эксплуатируемых месторождений вступила в стадию падающей добычи, а новые месторождения в большинстве случаев характеризуются худшими горно-геологическими и географическими параметрами, их разработка требует повышенных эксплуатационных и транспортных затрат.

В целом среднегодовая добыча за 1991-2015 гг. составила 377 млн т (рис. 3), среднегодовой прирост добычи нефти $-1,44$ млн т, или $0,64 \%$.

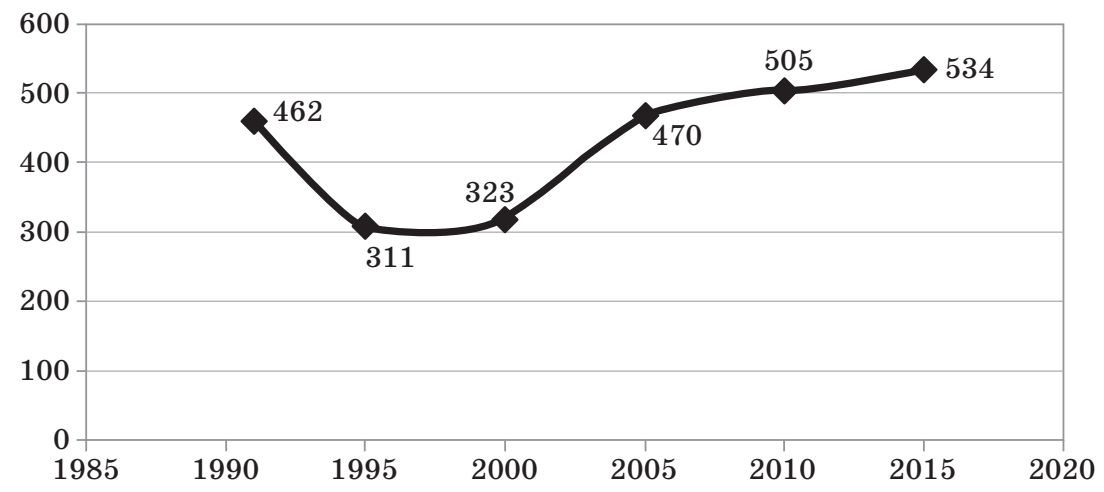

Рис. 3 Динамика добычи нефти в РФ за 1991-2015 г2., млн т (Источник: URL: http:// www/ minenergo.gov.ru)

На этапе зрелости значительно ухудшается состояние сырьевой базы, что ведет к увеличению себестоимости добычи нефти, также происходит неоправданное «запирание» огромных запасов нефти как «нерентабельных к разработке». В последние 15 лет прошедшего столетия объемы разведочного бурения сократились более чем в 4,5 раза, прирост запасов нефти почти в 7,0 раз. В результате ухудшения геологоразведочных работ прирост запасов нефти практически с 1994 г. уже даже не компенсирует добычу. Положение усугубляется тем, что за последнее десятилетие практически свернуто применение современных методов увеличения нефтеотдачи, без чего не возможна эффективная разработка трудных запасов, а значит и преодоление негативной тенденции снижения нефтеотдачи. Стоит также отметить, что не разрабатываются передовые отечественные методы увеличения нефтеотдачи и не поощряются научные разработки. Вследствие перечисленных факторов на данном этапе жизненного цикла отрасли наблюдаются следующие отрицательные явления:

- небольшой прирост запасов;

- снижение нефтеотдачи;

- осуществление добычи преимущественно из активной части запасов;

- увеличение затрат на добычу нефти.

\section{Baikal Research Journal}


Сравнительные характеристики фаз жизненного цикла нефтедобывающей отрасли РФ по количественным показателям свидетельствуют о том, что существует значительный разрыв в показателях первой и второй фаз, а между показателями второй и третьей фаз разница невелика (табл. 1). Однако среднегодовой прирост добычи, характеризующий годовые темпы прироста добычи нефти, в среднем за период на фазе рождения в 1,75 раз ниже, чем на фазе роста, а на фазе зрелости в 8,8 раз ниже, чем на фазе роста, что подтверждает правильность выделения фаз. Это же подтверждает и динамика среднегодовой выработки на 1 чел., занятого в нефтедобыче (см. табл. 1). Среднегодовой прирост выработки в среднем за период на фазе рождения в 1,6 раза ниже, чем на фазе роста, а на фазе зрелости в 2,18 раз ниже, чем на фазе роста.

\section{Сравнительная характеристика фаз жизненного цикла}

Таблица 1 нефтедобывающей отрасли РФ, млн т

\begin{tabular}{|l|r|r|r|}
\hline \multirow{2}{*}{ Показатели } & \multicolumn{3}{|c|}{ Фазы жизненного цикла } \\
\cline { 2 - 4 } & рождение & \multicolumn{1}{|c|}{ рост } & зрелость \\
\hline Среднегодовой объем добычи нефти & 44,6 & 409,8 & 377,0 \\
\hline Среднегодовой прирост добычи нефти & 7,3 & 12,8 & 1,4 \\
\hline Максимум годовой добычи нефти & 147,9 & 570,0 & 534,0 \\
\hline Минимум годовой добычи нефти & 18,4 & 166,0 & 303,0 \\
\hline $\begin{array}{l}\text { Среднегодовая выработка на 1 чел., занятого в нефтедо- } \\
\text { быче, тыс. т/чел. }\end{array}$ & 3,0 & 4,8 & 2,2 \\
\hline
\end{tabular}

За все время динамика добычи в данной отрасли вообе не носила характера плавного изменения - она состояла из ряда волн разной продолжительности. На фазе рождения, как уже отмечалось, наблюдался циклический характер (в основном роста), но тенденция среднегодовых темпов роста по периодам данной фазы разнилась. Так, в 1930-1941 гг. среднегодовой темп прироста добычи составил 4,7 \%, понижательная волна добычи наблюдалась в 1941-1945 гг., когда ее среднегодовой прирост характеризовался отрицательной величиной в $-9,6 \%$.

На фазе роста четко просматриваются два периода: повышательная волна (1961$1987)$ и понижательная волна (1988-1990).

На фазе зрелости также можно выделить две волны: 1991-1997 гг. и 19982015 гг. Однако они имеют сглаженный характер, отсутствуют глубокие спады (за исключением периода, пришедшегося на первые годы экономических реформ, системного экономического кризиса и коренной перестройки принципов управления нефтедобывающей отраслью России) и высокие пики. Такое изменение волнообразного характера развития добычи нефти также свидетельствует о смене фаз жизненного цикла отрасли.

По мнению авторов, циклические колебания в ходе развития отрасли помимо геологических факторов вызваны следующими причинами:

- чувствительность нефтедобывающей отрасли к организации управления ею. Спад добычи нефти в 1990-1998 гг. связан с разрушением хозяйственных связей в отрасли, изменением принципов государственного регулирования и поддержки отрасли, развалом единой отрасли и созданием ряда ВИНК;

- несоответствие спроса на продукцию отрасли и располагаемыми возможностями (производственная мощность);

- изменение выработки работающих, которая зависит от уровня организации производства и использования инновационных технологий.

Резюмируя, следует отметить, что нефтедобывающая отрасль РФ в настоящее время находится на фазе зрелости своего жизненного цикла. Этот вывод основан на анализе показателей добычи нефти с 1930 г. и по настоящее время.

\section{Baikal Research Journal}

электронный научный журнал Байкальского государственного университета 
Для отрасли, находящейся в фазе зрелости, дальнейшее развитие и увеличение длительности этой фазы должно быть связано, на наш взгляд, с переходом на инновационный путь развития. Это объясняют следующие обстоятельства:

1. За весь период функционирования отрасль развивается в зависимости от наличия месторождений, этот резерв практически исчерпан.

2. В отрасли наблюдается низкая конкуренция. Внутренний рынок поделен между несколькими крупными игроками (ВИНК), а экспорт напрямую контролируется государством. ВИНК блокируют любые попытки зародить в нефтедобыче конкуренцию.

3. Годовая выработка работающих в отрасли снижается, а это фактор, влияющий на длительность фазы жизненного цикла отрасли. Направление ее повышения - активизация инновационной деятельности.

4. Это отрасль «догоняющего развития», что определяется уровнем технического развития и понижением темпов прироста добычи нефти.

Таким образом, в настоящее время основополагающими факторами развития нефтедобывающей отрасли являются инновационные факторы, которые способствуют ее переводу на качественно новый тип развития, позволяющий приобретать важные свойства - стабильность и конкурентоспособность. Конкурентоспособная отрасль в большей степени подвержена положительной экономической динамике, находится в более выгодных условиях в отношении инновационного развития. При этом конкурентоспособность не только стимулирует инновационное развитие, но и является производным результатом инновационных усилий.

Для прогнозирования развития на основе стратегических альтернатив нами использовались методы математического моделирования. Модель жизненного цикла отрасли представляет собой нелинейный процесс эволюционного развития системы. В ряде работ [10-12] предлагается использовать различные экономические, экономико-математические, статистические, а также комплексные методы для анализа подобных процессов. В частности, для аналитического описания и прогнозирования эволюционных процессов предлагается использовать сигмондальные или логистические кривые, которые имеют несколько характерных периодов, а именно «латентный период» - зарождение процесса, далее «период роста» (высокие темпы), затем период резкого замедления роста параметров - «период сатурации» (насыщения). Общий вид кривой такого типа:

где $a, b, c,-$ параметры кривой.

$$
y=\frac{a}{b+c^{-c t}},
$$

Отношение $a$ / в определяет предельно-возможное значение роста, т. е. «предел насыщения»; c - характеризует скорость движения «предела насыщения» (темп роста). Точка $t$ (период времени) соответствует «точке перегиба»:

$$
t=\frac{\operatorname{Ln}\left(\frac{1}{b}\right)}{c} .
$$

Уравнения логистической кривой могут быть разного вида, в частности

$$
y_{t}=\frac{a}{b+c^{-c t}} .
$$

Однако для удобства расчетов, интерпретации параметров или в случае недостаточности объема информации удобнее использовать следующую формулу:

$$
y_{t}=\frac{K}{1+1_{0}(a+b+t)},
$$

где $K-$ «предел насыщения», о котором упоминалось ранее.

\section{Baikal Research Journal}


При приближении к периоду насыщения $\left(K \downarrow^{i}\right)$ необходим качественный скачок в точке «перегиба» (замедление темпов), для осуществления которого необходимо использовать инновационные возможности, что приведет к росту темпов развития и переходу на новый уровень.

При приближении к очередному моменту насыщения процесс разделения траектории повторяется. Таким образом, на каждом шаге появляется возможность рассчитать определенный прогнозный уровень (предел насыщения) в сложившихся технико-экономических условиях (рис. 4).

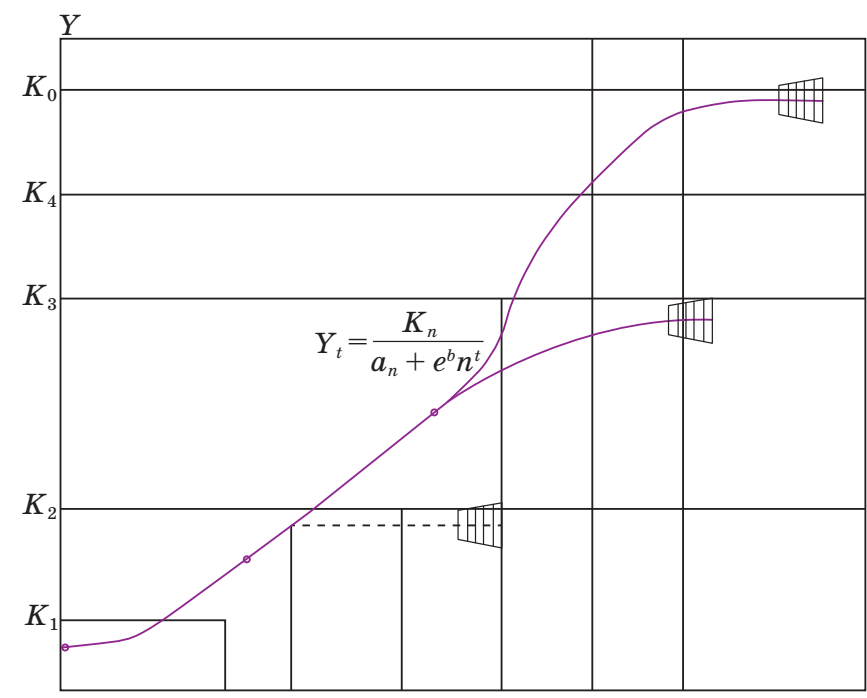

Рис. 4. Схела описания возложных этапов перспективного развития отрасли

Разработка таких сценариев носит как правило экстраполяционный характер и отвечает на вопрос: «Что будет, если...?». Однако возможное развитие сценария по другому варианту, который называется нормативно-целевой и отвечает на вопрос: «Что необходимо сделать, чтобы...?». В этом случае задается некоторый нормативный предел, и с помощью расчетов определяется возможная скорость (темпы роста) выбранных параметров для достижения определенной цели.

Для определения параметров логистических кривых (1), описывающих жизненный цикл нефтедобывающей отрасли, можно использовать метод трех точек: уровни динамики в начале, середине и в конце ряда [12]. Непременным условием применения данного метода является равенство расстояний между указанными уровнями.

Для построения логистической кривой были использованы показатели добычи нефти за 2003-2015 гг., которые дают достаточно достоверное представление о темпах развития отрасли (табл. 2).

Таблица 2

Объел добычи нефти в России в 2003-2015 г2., ллн т

\begin{tabular}{|c|r|c|r|}
\hline Год & Добыча & Год & Добыча \\
\hline 2003 & 421 & 2010 & 505 \\
\hline 2004 & 459 & 2011 & 511 \\
\hline 2005 & 470 & 2012 & 518 \\
\hline 2006 & 481 & 2013 & 523 \\
\hline 2007 & 491 & 2014 & 526 \\
\hline 2008 & 489 & 2015 & 534 \\
\hline 2009 & 494 & & \\
\hline
\end{tabular}

\section{Baikal Research Journal}


Были приняты следующие условия:

$$
y_{0}(2003)=421 ; \quad y_{1}(2010)=505 ; \quad y_{2}(2015)=534 \text {. }
$$

В результате расчетов было получено уравнение логистической функции

$$
y_{t}=\frac{545}{1+1,4 e^{-0,160-t}} .
$$

Сопоставление расчетных и фактических значений в исходных точках подтвердило хорошую аппроксимацию данного уравнения:

$$
y_{0}=425 ; \quad y_{1}=502,3 ; \quad y_{2}=532,4 \text {. }
$$

Средний темп добычи нефти за выбранные периоды составил:

$$
\begin{aligned}
& \bar{T}\left(y_{1}-y_{0}\right)=\sqrt[5]{\frac{502,3}{425}}=1,033 ; \\
& \bar{T}\left(y_{2}-y_{1}\right)=\sqrt[5]{\frac{532,4}{502,3}}=1,007 .
\end{aligned}
$$

Если предположить, что после 2015 г. в течение определенного периода темп роста добычи нефти сохранится на уровне $100,7 \%$, то «предел насыщения» данного периода $K=545$ млн т логистическая кривая достигнет к 2018 г. В 2016 г. объем добычи составит 537,7 млн т, в 2017 г. - 541,5 млн т, в 2019 г. $-549,1$ млн т, в 2020 г. - 553,0 млн т.

Сопоставим приведенные расчеты с показателями, заданными для нефтедобывающей отрасли России Стратегией развития нефтедобывающей отрасли на период до 2025 г. (табл. 3).

Объемы добычи нефти Россией в 2015-2025 22.

Таблица 3

\begin{tabular}{|l|l|l|l|l|l|l|l|l|l|}
\hline \multicolumn{1}{|c|}{ Приведенные расчеты } & 2015 & 2016 & 2017 & 2018 & 2019 & 2020 & 2021 & 2023 & 2025 \\
\hline $\begin{array}{l}\text { Стратегия развития нефте- } \\
\text { добывающей отрасли }\end{array}$ & 527,0 & 534,3 & 541,7 & 549,2 & 556,9 & 565,0 & 569,5 & 575,0 & 580,0 \\
\hline $\begin{array}{l}\text { Рассчитанные авторами } \\
\text { показатели }\end{array}$ & 534,0 & 537,7 & 541,5 & 545,3 & 549,1 & 553,0 & 556,9 & 565,0 & 572,6 \\
\hline
\end{tabular}

Расчеты показывают, что если, начиная с 2015 г. сохранять ежегодный прирост добычи нефти на уровне $0,7 \%$, то установленного стратегией показателя в 565 млн т, можно будет достичь в 2023 г. Опишем математическую закономерность, предлагаемую стратегией, принимая

$$
y_{0}(2015)=527 ; \quad y_{1}(2020)=565 ; \quad y_{2}(2025)=580,
$$

т. е. в данном случае $K=5$. Значения для 2025 г. были рассчитаны исходя из требований методики и сохранения среднего темпа роста добычи. В результате расчетов «предел насыщения» следующего этапа развития отрасли составит $K=570$ млн т. Для определения «точки перегиба», т. е. ситуации, когда необходимо внести качественные изменения в развитие системы, чтобы продлить ее функционирование, составим прогноз развития нефтедобывающей отрасли России. В этих целях был использован сценарный подход на основе метода стратегических ограничений [11]. Возможный сценарий развития добычи нефти в соответствии с проделанными расчетами представлен в табл. 4.

Расчеты показали, что при сохранении темпов роста добычи нефти на уровне $100,7 \%$ «предел насыщения» $K=545$ млн т будет достигнут в 2018 г.

Для дальнейшего развития нефтедобывающей отрасли потребуется качественный скачок в виде внедрения инноваций технологического, организационного, институци-

\section{Baikal Research Journal}


онального характера, который позволит повысить темпы роста добычи до $102 \%$ в год. Следующий «предел насыщения» $K=560$ млн т будет достигнут к 2021 г. Такой рост объемов добычи нефти возможен в случае активизации инновационной деятельности в отрасли, которая позволит продлить фазу зрелости жизненного цикла отрасли и повысить темпы добычи. Дальнейшее развитие отрасли, на наш взгляд, будет определяться не наращиванием объемов добычи, которые ограничены возможностями сырьевой базы, а новыми технологиями нефтедобычи и воспроизводством сырьевой базы.

Таблица 4

Сиенарный подход к развитию нефтедобывающей отрасли России в 2015-2026 г2.

\begin{tabular}{|c|r||c|r|}
\hline Год & $T=100,7 \% ; K=545$ & Год & $T=102,0 \% ; K=570$ \\
\hline 2015 & 534,0 & 2021 & 564,0 \\
\hline 2016 & 537,7 & 2022 & 575,3 \\
\hline 2017 & 541,5 & 2023 & 586,8 \\
\hline 2018 & 545,3 & 2024 & 598,5 \\
\hline 2019 & 549,1 & 2025 & 610,4 \\
\hline 2020 & 553,0 & 2026 & 622,8 \\
\hline
\end{tabular}

В результате проведенных исследований были сделаны следующие выводы:

1. Разработан методический подход к формированию фаз жизненного цикла нефтедобывающей отрасли. С этой целью выявлена специфика ресурсных отраслей. Для выделения фаз жизненного цикла проанализированы данные, отражающие динамику развития отрасли с 1930 по 2015 г., выявлены особенности каждой фазы, рассчитаны показатели. Представлена сравнительная характеристика фаз жизненного цикла отрасли.

2. Выявлены причины циклического развития отрасли на каждой фазе жизненного цикла и дана их характеристика.

3. Сформированы направления возможного увеличения длительности фаз жизненного цикла и, соответственно, темпов роста добычи нефти.

4. В качестве математического инструментария обоснования выделения этапов реализации стратегии роста добычи нефти предлагается использовать логистические кривые, с помощью которых можно рассчитать определенный прогнозный уровень «предел насыщения» в сложившихся технико-экономических условиях. Для его преодоления необходим «качественный скачок» в точке «перегиба» (замедления темпов), что приведет к переходу отрасли на новый уровень развития.

\section{Список использованной литературы}

1. Щербенко Е. В. Механизмы устойчивого развития экономики отрасли [Электронный ресурс] / Е. В. Щербенко // Проблемы современной экономики. - 2008. - № 3 (27). - С. 41-49.

2. Портер М. Конкурентная стратегия. Методика анализа отраслей и конкурентов : пер. с англ. / М. Портер. - М. : Альпина Бизнес Букс, 2005. - 454 с.

3. Экономические кризисы, кризисные явления и антикризисное управление / Г. В. Давыдова, А. Ю. Беликов, Т. А. Кондрацкая, Е. М. Новицкая, С. В. Чупров. - Иркутск : Изд-во БГУЭП, 2006. - 317 с.

4. Беликов А. Ю. Проблемы учета фактора времени при анализе экономических циклов / А. Ю. Беликов. - Иркутск : Изд-во БГУЭП, 2010. - 192 с.

5. Любушин Н. П. Концепция жизненного цикла: от качественного описания к количественной оценке / Н. П. Любушин, Н. Э. Бабичева // Экономический анализ: теория и практика. -2010 . - № 23. - С. 2-7.

6. Янсен Ф. Эпоха инноваций. Как заниматься бизнесом творчески постоянно, а не от случая к случаю : пер. с англ. / Ф. Янсен. - М. : Инфра-М, 2002. - 308 с.

7. Садченко К. В. Законы экономической эволюции / К. В. Садченко. - М. : Дело и сервис, 2007. $-272 \mathrm{c.}$

\section{Baikal Research Journal}


8. Матвейчук А. А. У истоков нефтяной промышленности России / А. А. Матвейчук. М. : Известия, 2000. - 231 с.

9. Демин С. Ю. О некоторых чертах современного нефтяного рынка России / С. Ю. Демин, Н. Н. Баторов // Вестник Иркутского регионального отделения Академии наук Высшей школы РФ. - 2006. - № 1. - С. 74-80.

10. Форлеченкова Л. В. Анализ факторов конкурентоспособности организаций на различных стадиях жизненного цикла / В. Форлеченкова // Экономический анализ: теория и практика. - 2010. - № 33. - С. 46-52.

11. Саркисян С. А. Прогнозирование развития больших систем / С. А. Саркисян, Л. В. Голованов. - М. : Статистика, 1975. - 192 с.

12. Четыркин Е. М. Статистические методы прогнозирования / Е. М. Четыркин. 2-е изд., перераб. и доп. - М. : Статистика, 1977. - 200 с.

\section{References}

1. Shcherbenko E. V. Mechanisms of sustainable development of the branch economy. Problemy sovremennoi ekonomiki = Problems of Modern Economy, 2008, no. 3 (27), pp. 41-49. (In Russian).

2. Porter Michael E. Competitive Strategy: Techniques for Analyzing Industries and Competitors. The Free Press, 1998. 454 p. (Russ. ed.: Porter M. Konkurentnaya strategiya. Metodika analiza otraslei i konkurentov. Moscow, Al'pina Biznes Buks Publ., 2005. 454 p.).

3. Davydova G. V., Belikov A. Yu., Kondratskaya T. A., Novitskaya E. M., Chuprov S. V. Ekonomicheskie krizisy, krizisnye yavleniya i antikrizisnoe upravlenie [Economic crises, crisis phenomena and anti-crisis management]. Irkutsk, Baikal State University of Economics and Law Publ., 2006. 317 p.

4. Belikov A. Yu. Problemy ucheta faktora vremeni pri analize ekonomicheskikh tsiklov [Problems of time factor management in analyzing economic cycles]. Irkutsk, Baikal State University of Economics and Law Publ., 2010. 192 p.

5. Lyubushin N. P., Babicheva N. E. Concept of life cycle: from qualitative description to quantitative assessment. Ekonomicheskii analiz: teoriya $i$ praktika $=$ Economic Analysis: Theory And Practice, 2010, no. 23, pp. 2-7. (In Russian).

6. Janszen F. The Age of Innovation: Making Business Creativity a Competence, Not a Coincidence. London, New-York, Financial Times - Prentice-Hall, 2000. (Russ. ed.: Janszen F. Epokha innovatsii. Kak zanimat'sya biznesom tvorcheski postoyanno, a ne ot sluchaya $k$ sluchayu. Moscow, Infra-M Publ., 2002. 308 p.).

7. Sadchenko K. V. Zakony ekonomicheskoi evolyutsii [Laws of Economic Evolution]. Moscow, Delo i servis Publ., 2007. 272 p.

8. Matveichuk A. A. U istokov neftyanoi promyshlennosti Rossii [At the onset of Russia's oil production]. Moscow, Izvestiya Publ., 2000. 231 p.

9. Demin S. Yu., Batorov N. N. On some traits of Russia's present-day oil market. Vestnik Irkutskogo regional'nogo otdeleniya Akademii nauk Vysshei shkoly $R F=$ Bulletin of Irkutsk Regional Branch of RF Higher School Academy of Sciences, 2006, no. 1, pp. 74-80. (In Russian).

10. Forlechenkova L. V. Analysis of corporations' competitiveness factors at various stages of life cycle. Ekonomicheskii analiz: teoriya i praktika = Economic Analysis: Theory And Practice, 2010, no. 33, pp. 46-52. (In Russian).

11. Sarkisyan S. A., Golovanov L. V. Prognozirovanie razvitiya bol'shikh sistem [Forecasting of big systems development]. Moscow, Statistika Publ., 1975. 192 p.

12. Chetyrkin E. M. Statisticheskie metody prognozirovaniya [Statistical methods of forecasting]. $2^{\text {nd }}$ ed. Moscow, Statistika Publ., 1977. 200 p.

\section{Информация об авторах}

Давыдова Галина Васильевна - доктор экономических наук, профессор, кафедра экономики и управления бизнесом, Байкальский государственный университет, 664003, г. Иркутск, ул. Ленина, 11, e-mail: davidova@isea.ru.

Козлова Ольга Сергеевна - аспирант, кафедра экономики и управления бизнесом, Байкальский государственный университет, 664003, г. Иркутск, ул. Ленина, 11, e-mail: Okozlova81@mail.ru.

\section{Baikal Research Journal}




\section{Authors}

Galina V. Davydova - Doctor habil. (Economics), Professor, Chair of Economics and Business Management, Baikal State University, 11 Lenin St., 664003, Irkutsk, Russian Federation; e-mail: davidova@isea.ru.

Olga S. Kozlova - PhD Student, Chair of Economics and Business Management, Baikal State University, 11 Lenin St., 664003, Irkutsk, Russian Federation; e-mail: Okozlova81@mail.ru.

\section{Библиографическое описание статьи}

Давыдова Г. В. Влияние жизненного цикла нефтедобывающей отрасли на стратегические альтернативы ее развития / Г. В. Давыдова, О. С. Козлова // Baikal Research Journal. 2016. 一 T. 7, № 5. — DOI : 10.17150/2411-6262.2016.7(5).7.

\section{Reference to article}

Davydova G. V., Kozlova O. S. Impact of life cycle of oil-producing industry on strategic alternatives of its development. Baikal Research Journal, 2016, vol. 7, no. 5. DOI : 10.17150/24116262.2016.7(5).7. (In Russian).

\section{Baikal Research Journal}

